\title{
THE EFFECT OF CADMIUM ON OXIDATIVE STRESS IN Beta vulgaris
}

\author{
WPEYW KADMU NA STRES OKSYDACYJNY U Beta vulgaris
}

\begin{abstract}
As a heavy metal, cadmium has strongly toxic effects on plants and can induce oxidative stress. It is absorbed by the roots and transported to the stems and leaves. The aim of the study was to evaluate the effect of various concentrations of cadmium on the metabolic activity of Beta vulgaris and assess the dependence of these processes on the content of metal in the plants. To demonstrate the effect of cadmium on metabolism, protein and photosynthetic pigment content, lipid peroxidation, and the activity of enzymes specific for oxidative stress in roots and shoots were measured. Seeds of $B$. vulgaris were treated with different concentrations of Cd supplied via a $\mathrm{CdCl}_{2}$ solution: 0 (control), 200, 300 and $400 \mathrm{mg} / \mathrm{dm}^{3}$. Results of the present study revealed increased GPOX activity as cadmium concentration rose, while SOD activity was stimulated by a low Cd concentration $\left(200 \mathrm{mg} / \mathrm{dm}^{3}\right)$ and reduced by high levels of Cd. Based on the present findings, it can be concluded that GPOX in B. vulgaris played a more important role in ROS scavenging than SOD did and was able to reduce the level of lipid peroxidation in plants. Cadmium, in the concentration range used, did not show any significant effect on protein or photosynthetic pigment content.
\end{abstract}

Keywords: Beta vulgaris, cadmium, oxidative stress

\section{Introduction}

Heavy metals are elements naturally occurring in the Earth's crust. Many have strongly toxic effects [1, 2]. One of them is cadmium [3]. In the natural environment, cadmium is often associated with lead and zinc ores [4]. In noncontaminated soil, Cd concentration varies from 0.01 to $5.0 \mathrm{mg} / \mathrm{kg}$ [5]. However, it is estimated that about $30,000 \mathrm{Mg}$ of cadmium are released into the environment every year. This pollution originates mainly from cement production, the metallurgical industry, fossil fuel combustion and the use of artificial fertilizers $[6,7]$.

For higher plants, cadmium has no biological function. It is absorbed by the roots and transported to the stems and leaves via the symplast and apoplast pathways [8,9]. Plants activate various mechanisms in response to the presence of cadmium, including chelation, active transport into the vacuole, immobilization, and compartmentalization of metal ions. Stress protein expression and increased ethylene production have also been observed [5].

\footnotetext{
${ }^{1}$ Independent Chair of Biotechnology and Molecular Biology, University of Opole, ul. kard. B. Kominka 6, 45-032 Opole, Poland, phone +48 774016050

*Corresponding author: agarombel@uni.opole.pl
} 
The most general symptoms of $\mathrm{Cd}$ stress are declines in chlorophyll content and inhibited photosynthesis, which manifest as less growth and reduced leaf area [10, 11]. Furthermore, Cd stress increases reactive oxygen species (ROS) levels, which can lead to damage to vital molecules, such as proteins, lipids, DNA and RNA [12]. Those impairments can generate a metabolic malfunction in cells and, as a result, may cause cell death [13].

ROS are reactive atoms or molecules found in all aerobic organisms. Free radical ROS, including hydroxyl radicals, alkoxy radicals, perhydroxyl radicals and superoxide radicals, as well as non-radical forms (singlet oxygen and hydrogen peroxide), are naturally produced in the mitochondria and chloroplasts of plants and animals.

ROS overproduction causes oxidative stress and activates various defense mechanisms. Organisms use antioxidant enzymes, including ascorbate peroxidase, superoxide dismutase and catalase, to reduce the amount of ROS [13, 14]. Non-enzymatic defense mechanisms include glutathione, non-protein amino acids, phenolic compounds and ascorbic acid $[14,15]$.

The aim of this study was an experimental study of Beta vulgaris, measuring metabolic stress under the influence of cadmium in various concentrations and assessing the dependence of these processes on the content of metal in the plants.

To demonstrate the effect of cadmium on metabolism, protein and photosynthetic pigment content, lipid peroxidation, and the activity of enzymes specific for oxidative stress were determined.

\section{Materials and methods}

\section{Plant materials and treatments}

Seeds of B. vulgaris $(7 \mathrm{~g})$ were sterilized in a $5 \%(\mathrm{w} / \mathrm{v}) \mathrm{H}_{2} \mathrm{O}_{2}$ solution for $10 \mathrm{~min}$ and then treated with different concentrations of $\mathrm{Cd}$ supplied via a $\mathrm{CdCl}_{2}$ solution: 0 (control), 200, 300 and $400 \mathrm{mg} / \mathrm{dm}^{3}$. Each treatment was done in three replicates. After 12 hours of $\mathrm{Cd}$ treatment, the seeds were washed with sterile water and sown in plastic pots filled with perlite. The cultivation was carried out in a growth chamber in a photoperiodic system day/night $14 / 10$ hours at a temperature of $20 / 16{ }^{\circ} \mathrm{C}$, respectively, with $80 \%$ relative humidity. Irrigation via a Knap solution was provided regularly in sufficient quantities for plant growth.

\section{Enzyme extractions and assay}

The roots and shoots samples $(1 \mathrm{~g})$ were ground separately in liquid $\mathrm{N}_{2}$ using a mortar and pestle, after which the ground material was homogenized on ice in $2 \mathrm{~cm}^{3}$ of a $50 \mathrm{mM}$ sodium phosphate buffer $(\mathrm{pH}=7.0)$. The homogenates were centrifuged at 10,000 rpm (revolutions per minute) for $20 \mathrm{~min}$ at $4{ }^{\circ} \mathrm{C}$. The supernatants were used in the determination of guaiacol peroxidase (GPOX, EC 1.11.1.7) and superoxide dismutase (SOD, EC 1.15.1.1) activity and protein content.

GPOX activity was determined spectrophotometrically using guaiacol as the substrate and $\mathrm{H}_{2} \mathrm{O}_{2}$ as the hydrogen donor. Colored tetraguaiacol $\left(\varepsilon=26.6 \mathrm{mM}^{-1} \mathrm{~cm}^{-1}\right)$ is formed in guaiacol oxidation process. The specific GPOX activity was determined according to the modified method by Zaharieva et al. [16]. The reaction mixture $\left(5.0 \mathrm{~cm}^{3}\right)$ consisted of a $50 \mathrm{mM}$ phosphate buffer $(\mathrm{pH}=7.0), 38 \mathrm{mM}$ of $\mathrm{H}_{2} \mathrm{O}_{2}$ and $4 \mathrm{mM}$ of guaiacol. The reaction was started by the addition of $0.2 \mathrm{~cm}^{3}$ of the supernatant (enzyme extract). The increase in 
absorbance was measured at $470 \mathrm{~nm}$ for 1-minute intervals up to 5 minutes. The enzyme activity was expressed in $\mu \mathrm{mol}$ per minute and milligrams of protein.

SOD activity was determined by its ability to inhibit autooxidation of adrenaline and thereby prevent the formation of active forms of oxygen [17]. To prepare this, $0.055 \mathrm{~cm}^{3}$ of a $0.18 \%$ (5.46 mmol) pharmacy solution of adrenaline hydrochloride was added to $2 \mathrm{~cm}^{3}$ of a $0.2 \mathrm{M}$ sodium carbonate buffer $(\mathrm{pH}=10.65)$, then mixed thoroughly and rapidly. Absorption intensity was determined every 30 seconds for 5 minutes at a wavelength of $340 \mathrm{~nm}\left(\mathrm{~A}_{1}\right), 0.01 \mathrm{~cm}^{3}$ of the enzyme extract and $0.055 \mathrm{~cm}^{3}$ of $0.18 \%$ adrenaline hydrochloride were added to $2 \mathrm{~cm}^{3}$ of buffer $(\mathrm{pH}=10.65)$ and stirred, and the absorption intensity was measured as described above $\left(\mathrm{A}_{2}\right)$. The blank was a buffered enzyme extract, without adrenaline. Antioxidant activity (AA) of the studied enzyme extracts were expressed as the percent inhibition of autooxidation of adrenaline and calculated by the formula:

$$
A A=\frac{\left(A_{1}-A_{2}\right) \cdot 100 \%}{A_{1}}
$$

One unit of SOD activity was defined as the amount of enzyme that caused the inhibition of autooxidation of adrenaline by $50 \%$. Enzyme activity was expressed in units per minute and milligrams of protein.

\section{Determination of protein content}

The amount of total protein of the roots and shoots samples was measured using the Bradford method with bovine serum albumin (BSA) as the standard [18]. Absorption intensity of the extract was determined at a wavelength of $595 \mathrm{~nm}$ and the results were reported in $\mathrm{mg} / \mathrm{g}$ f.m. (fresh mass).

\section{Determination of photosynthetic pigments content}

The content of photosynthetic pigments was determined by acetone extraction. Briefly, $0.1 \mathrm{~g}$ of roots and shoots samples were homogenized separately using a chilled mortar and pestle with $5 \mathrm{~cm}^{3}$ of $80 \%(\mathrm{v} / \mathrm{v})$ acetone. The homogenates were centrifuged at 10,000 rpm for $10 \mathrm{~min}$ at $4{ }^{\circ} \mathrm{C}$. The absorbance of the supernatant was measured at 647, 663 and $470 \mathrm{~nm}$. The contents of chlorophyll $a$, chlorophyll $b$ and carotenoids were calculated according to Lichtenthaler [19] and are given in $\mathrm{mg} / \mathrm{g}$ f.m.

\section{Determination of lipid peroxidation}

Lipid peroxidation was expressed by the malondialdehyde (MDA) content, determined by the thiobarbituric acid (TBA) reaction described by Heath and Packer [20]. Briefly, $0.3 \mathrm{~g}$ of roots and shoots samples were homogenized separately in $4 \mathrm{~cm}^{3}$ of $0.25 \%(\mathrm{w} / \mathrm{v})$ thiobarbituric acid (TBA) in $10 \%(\mathrm{w} / \mathrm{v})$ trichloroacetic acid (TCA) using a mortar and pestle. The homogenates were heated at $95{ }^{\circ} \mathrm{C}$ for $30 \mathrm{~min}$, quickly cooled in an ice bath and then centrifuged at $10,000 \mathrm{rpm}$ for $10 \mathrm{~min}$. The absorbance of the supernatant was recorded at $532 \mathrm{~nm}$ and $600 \mathrm{~nm}$. The blank was $0.25 \%$ TBA in $10 \%$ TCA. The MDA concentration was calculated by subtracting the absorbance at $600 \mathrm{~nm}$ (nonspecific turbidity) using the extinction coefficient of $155 \mathrm{mM}^{-1} \cdot \mathrm{cm}^{-1}$ and expressed in terms of nmol/g f.m. [21]. 


\section{Determination of cadmium content}

The roots and shoots samples (the dry mass of each was $0.400 \pm 0.001 \mathrm{~g}$ ) were mineralized in a mixture of nitric $(\mathrm{V})$ acid and hydrochloric acid $\left(\mathrm{HNO}_{3} 65 \%: \mathrm{HCl} 37 \%=\right.$ $=1: 3$ ) using a Speedwave Four microwave oven (Berghof, Germany). The mineralization process temperature was $180{ }^{\circ} \mathrm{C}$. Reagents (Merck, USA) were used to prepare solutions [22]. Cadmium was determined with the atomic absorption spectrometer iCE 3000 (Thermo Electron Corporation, USA). The Instrument Detection Limit (IDL) and the Instrument Quantification Limit $(I Q L)$ for cadmium were 0.0028 and $0.013 \mathrm{mg} / \mathrm{dm}^{3}$, respectively. The highest concentration of the calibration standard available from ANALYTIKA Ltd. (Czech Republic), $2.5 \mathrm{mg} / \mathrm{dm}^{3}$, was adopted as the upper limit of the linear relation between the concentration of the analyte and the instrument signal [23]. The quality control of measurements was conducted using test analyses of the BCR 414 plankton and BCR-482 lichen reference materials (Institute for Reference Materials and Measurements, Belgium). The obtained results are summarized in Table 1.

Table 1

Measured and certified values of Cd concentration in the BCR 414 plankton and the BCR 482 lichen reference material

\begin{tabular}{|c|c|c|c|c|c|c|c|c|c|}
\hline \multicolumn{5}{|c|}{ BCR 414 plankton } & \multicolumn{5}{|c|}{ BCR 482 lichen } \\
\hline \multirow{2}{*}{$\begin{array}{c}\text { Certified } \\
\text { value }\end{array}$} & \multirow{2}{*}{ \pm Uncertainty } & \multicolumn{2}{|c|}{ AAS } & \multirow{2}{*}{$D^{*}$} & \multirow{2}{*}{$\begin{array}{c}\text { Certified } \\
\text { value }\end{array}$} & \multirow{2}{*}{ \pm Uncertainty } & \multicolumn{2}{|c|}{ AAS } & \multirow{2}{*}{$D^{*}$} \\
\hline & & Mean & $\pm S D$ & & & & Mean & $\pm S D$ & \\
\hline \multicolumn{4}{|c|}{ [mg/kg d.m.] } & {$[\%]$} & \multicolumn{4}{|c|}{ [mg/kg d.m.] } & {$[\%]$} \\
\hline 0.383 & 0.014 & n.d. & n.d. & n.d. & 0.56 & 0.02 & 0.53 & 0.03 & -5.3 \\
\hline
\end{tabular}

* Deviation - the difference between the measured value and the certified value, divided by the certified value n.d. - not detected

\section{Statistical analysis}

All experiments were carried out three times, with results expressed as mean values \pm standard deviation. One-way analysis of variances (ANOVA) and t-Student's test were used to determine statistical differences between the treatment samples and the control using Excel (Microsoft, USA). Differences were considered significant at the level of $p<0.05$. In order to assess the interdependence of cadmium content in B. vulgaris roots and shoots and the tested oxidative stress markers, a correlation analysis was performed using Excel (Microsoft, USA).

\section{Results}

\section{Protein content}

The effect of different $\mathrm{Cd}$ concentrations on protein content in the roots and shoots of B. vulgaris is shown in Figure 1. In the concentration range used, cadmium did not show any significant effect on protein content in either part of the plant. 


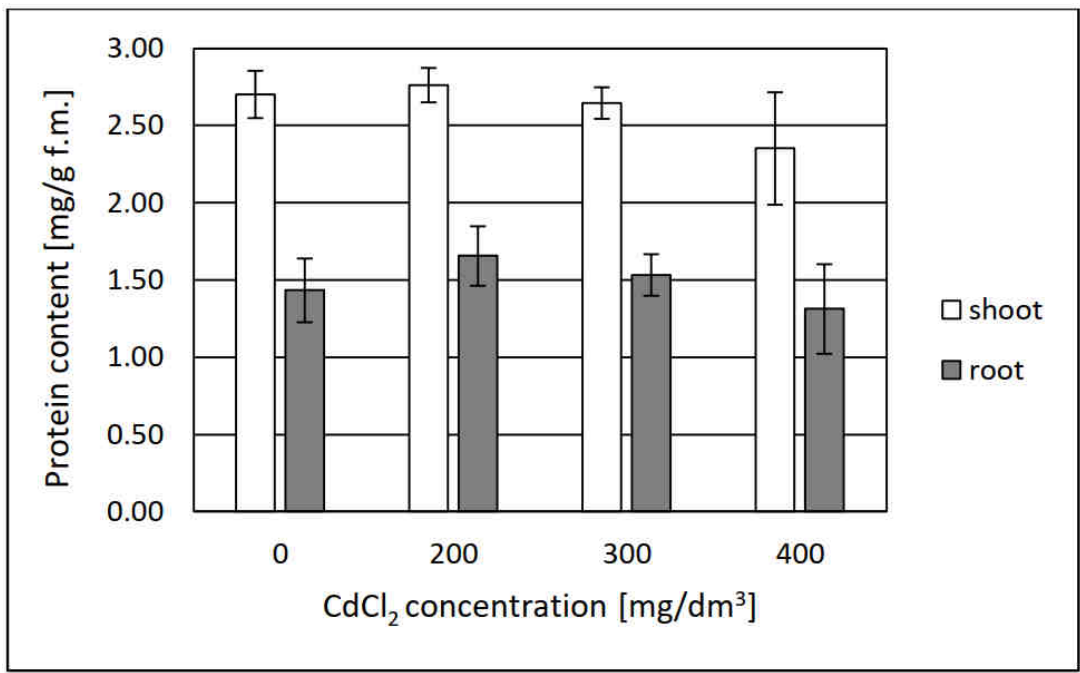

Fig. 1. The effect of different cadmium concentrations on protein content in Beta vulgaris plants (bars represent standard deviation); ANOVA, $p>0.05$ (shoot), $p>0.05$ (root)

\section{Superoxide dismutase activity}

The effect of different Cd concentrations on SOD activity in the roots and shoots of B. vulgaris is shown in Figure 2. The activities of this enzyme were higher in roots than shoots. For shoots, cadmium did not show any significant effect on SOD activity in the concentration range used. For roots, superoxide dismutase activity increased with a lower concentration of $\mathrm{Cd}$, whereas a significant decrease was observed in response to higher concentrations of the metal $\left(300\right.$ and $\left.400 \mathrm{mg} / \mathrm{dm}^{3}\right)$.

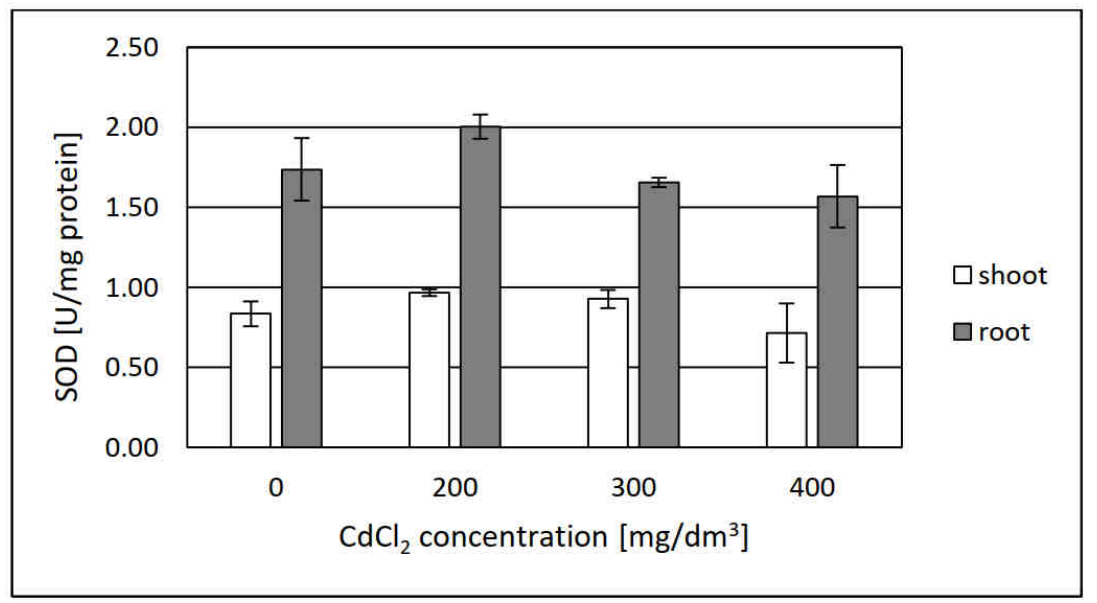

Fig. 2. The effect of different cadmium concentrations on the activity of superoxide dismutase (SOD) in Beta vulgaris plants (bars represent standard deviation); ANOVA $p>0.05$ (shoot), $p<0.05$ (root) 


\section{Guaiacol peroxidase activity}

The effect of different Cd concentrations on GPOX activity in the roots and shoots of B. vulgaris is shown in Figure 3 . The activity of the enzyme involved in the removal of $\mathrm{H}_{2} \mathrm{O}_{2}$ was higher in roots than in shoots. Furthermore, in both parts of the plant, the activity of GPOX significantly increased as cadmium concentration increased. In the case of roots, a higher concentration of $\mathrm{Cd}\left(400 \mathrm{mg} / \mathrm{dm}^{3}\right)$ slightly reduced GPOX activity.

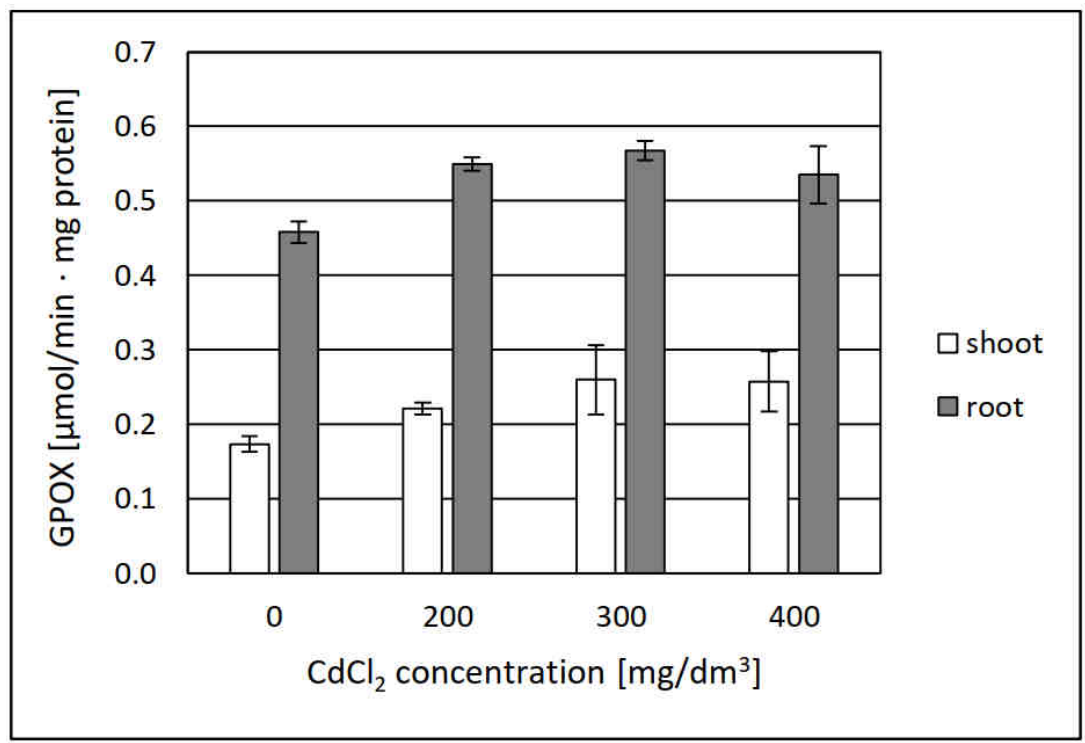

Fig. 3. The effect of different cadmium concentrations on the specific activity of guaiacol peroxidase (GPOX) in Beta vulgaris plants (bars represent standard deviation); ANOVA, $p<0.05$ (shoot), $p<0.05$ (root)

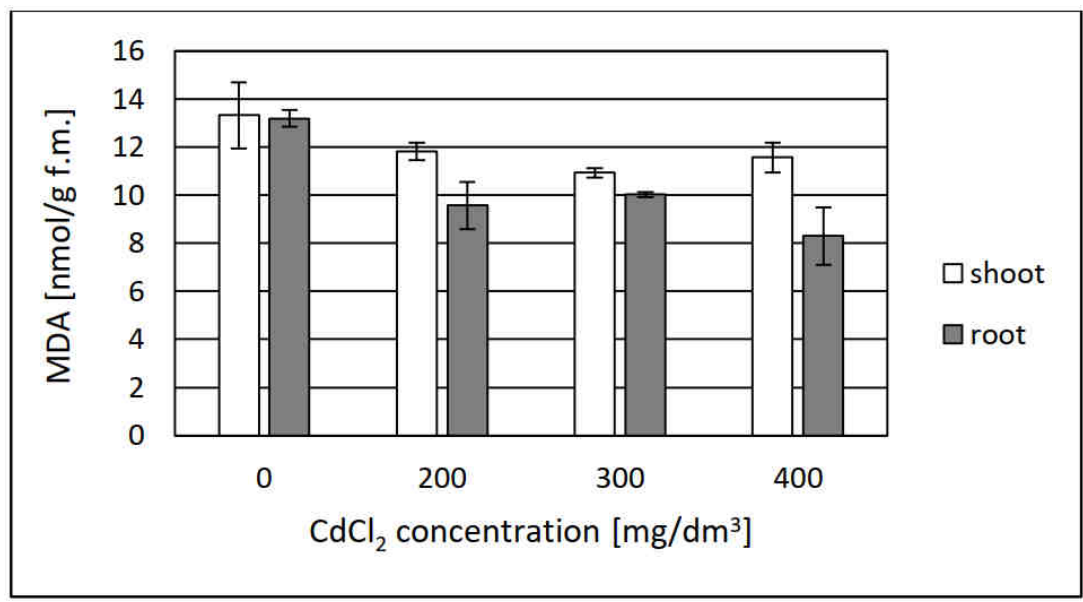

Fig. 4. The effect of different cadmium concentrations on malondialdehyde (MDA) content in Beta vulgaris plants (bars represent standard deviation); ANOVA, $p<0.05$ (shoot), $p<0.001$ (root) 


\section{Lipid peroxidation}

Levels of lipid peroxidation in plant tissues of $B$. vulgaris were expressed as MDA content and were significantly lower in samples treated with Cd compared to the control (Fig. 4). However, no significant differences were found in any of the samples treated with Cd.

\section{Photosynthetic pigments content}

The effects of $\mathrm{Cd}$ on photosynthetic pigments content are shown in Figure 5. No significant differences were observed in pigments content between Cd-treated samples and the control.

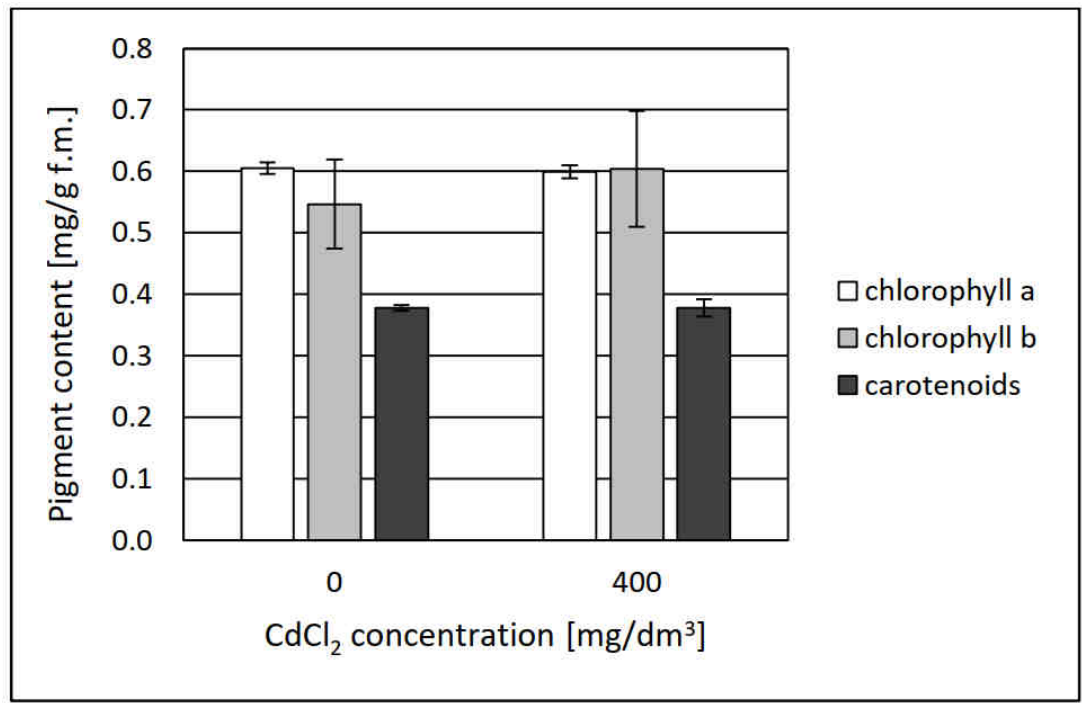

Fig. 5. The effect of different cadmium concentrations on photosynthetic pigments content in Beta vulgaris shoots (bars represent standard deviation); ANOVA, chl. $a p>0.05$, chl. $b p>0.05$, carotenoids $p>0.05$

\section{Cadmium content}

The cadmium content in plant tissues depended on the concentration of $\mathrm{CdCl}_{2}$ solution applied during the seed soaking process (Fig. 6). The seedlings not treated with cadmium had trace concentrations of $\mathrm{Cd}$ in both roots and shoots. The roots and shoots of control seedlings contained up to $0.39 \mathrm{mg} \mathrm{Cd} / \mathrm{kg} \mathrm{d} . \mathrm{m}$. (dry mass). Exposure of the seeds to excess $\mathrm{Cd}$ caused a rapid increase in $\mathrm{Cd}$ content in the plants. Maximum uptake ( $278.08 \mathrm{mg} / \mathrm{kg} \mathrm{d.m}$. in roots and $90.18 \mathrm{mg} / \mathrm{kg} \mathrm{d.m}$. in shoots) was noted in the $400 \mathrm{mg} / \mathrm{dm}^{3}$ treated plants. No significant differences were observed in root $\mathrm{Cd}$ content between the samples of 300 and $400 \mathrm{mg} / \mathrm{dm}^{3} \mathrm{CdCl}_{2}$ treatment. Furthermore, cadmium accumulated more in roots than in shoots (3.8 times more for the $\mathrm{CdCl}_{2}$ concentrations $200 \mathrm{mg} / \mathrm{dm}^{3}, 5$ times more for $300 \mathrm{mg} / \mathrm{dm}^{3}, 3$ times more for $400 \mathrm{mg} / \mathrm{dm}^{3}$ ). 


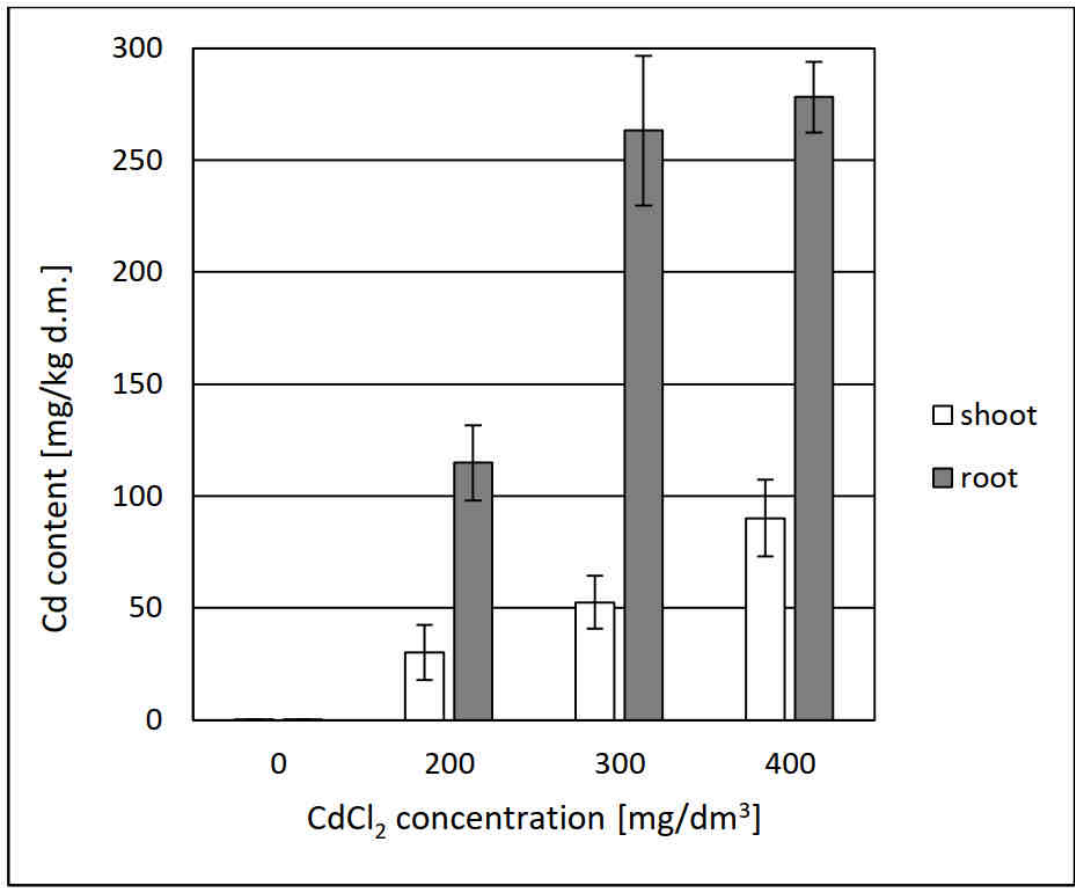

Fig. 6. The effect of different cadmium concentrations on cadmium content in Beta vulgaris plants (bars represent standard deviation); ANOVA, $p<0.001$

Table 2

Correlation between cadmium content in $B$. vulgaris plants and MDA concentration, GPOX and SOD activity

\begin{tabular}{|c|c|c|c|}
\hline \multirow{2}{*}{ Part of plant } & \multicolumn{3}{|c|}{ Correlation coefficient $\boldsymbol{R}$} \\
\cline { 2 - 4 } & Cd content/MDA & Cd content/GPOX activity & Cd content/SOD activity \\
\hline Root & -0.79 & 0.68 & -0.45 \\
\hline Shoot & -0.51 & 0.55 & -0.32 \\
\hline
\end{tabular}

The correlation between cadmium content in the roots and shoots of B. vulgaris and the concentration of MDA and antioxidant enzymes activity was investigated (Table 2). The analysis revealed a strong negative correlation between cadmium content and MDA concentration. In addition, a strong positive correlation between the plant's cadmium content and GPOX activity and a moderate negative correlation between its cadmium content and SOD activity were found.

\section{Discussion}

The main mechanism of cadmium phytotoxicity is the induction of oxidative stress. During Cd stress, systems capable of preventing excessive oxidation are induced or stimulated. These systems include some enzymes, such as superoxide dismutase (SOD) and peroxidases such as GPOX [24].

Superoxide dismutase constitutes the first line of defense against ROS by transforming $\mathrm{O}_{2}{ }^{-}$into $\mathrm{O}_{2}$ and $\mathrm{H}_{2} \mathrm{O}_{2}$ [25]. In multiple studies, there have been varying outcomes on SOD 
activity in plants exposed to Cd [26]. In this study, SOD activity in roots was stimulated by low Cd concentration $\left(200 \mathrm{mg} / \mathrm{dm}^{3}\right)$. However, high levels of $\mathrm{Cd}$ concentration diminished SOD activity compared to the control and $200 \mathrm{mg} / \mathrm{dm}^{3}$ concentration sample. These changes were similar to those in previous studies, where SOD activity in plants increased under low heavy metal concentrations and decreased under high concentrations, possibly as a result of a more severe degree of metal toxicity [27-31].

Peroxidases are important enzymes in plants that are able to lower oxidative stress induced by heavy metals. The main function of peroxidases is scavenging $\mathrm{H}_{2} \mathrm{O}_{2}$ in the cells. Guaiacol peroxidase utilizes $\mathrm{H}_{2} \mathrm{O}_{2}$ by oxidizing co-substrates such as phenolic compounds and/or antioxidants [32]. In this study, the GPOX activity in both roots and shoots significantly increased with higher cadmium concentration. This result was also obtained in other research, although GPOX activity varied based on $\mathrm{Cd}$ concentration and the plant species used [30, 33-36]. The higher activity of GPOX can explain the remarkably low concentration of MDA in B. vulgaris treated with $\mathrm{Cd}$ and the reduction in the lipid peroxidation level. These results indicated that GPOX in B. vulgaris played a more important role in ROS scavenging than SOD did. Furthermore, SOD and GPOX activity was approximately $50 \%$ higher in roots compared to shoots. The roots also accumulated more cadmium than shoots (up to 5 times more for $300 \mathrm{mg} / \mathrm{dm}^{3}$ of $\mathrm{CdCl}_{2}$ ). In most plant species, cadmium and other heavy metals mainly accumulate in roots [28, 35, 37-41]. The results suggest that increased accumulation of $\mathrm{Cd}$ in the roots of $B$. vulgaris stimulates GPOX activity, which protects cells from the negative effects of ROS.

In numerous other studies, chlorophyll and carotenoids have proven very sensitive to oxidative stress induced by $\mathrm{Cd}[35,36,42]$. In the present study, however, there was no effect on photosynthetic pigments content in response to $\mathrm{Cd}$, in the concentrations used. Similar results were observed in Cd-exposed Vicia faba [30].

In our study, there was no significant change in protein content under $\mathrm{Cd}$ stress (in the concentration range used). Similar findings were observed in garden cress, mustard and rapeseed, which could be due to the induction of synthesis of stress proteins [30, 42, 43].

\section{Conclusion}

Cadmium, in the concentration range used, did not show any significant effect on protein and photosynthetic pigments content in the roots and shoots of Beta vulgaris. Furthermore, the results of the present study revealed increased GPOX activity as cadmium concentration rose, while SOD activity was stimulated by low $\mathrm{Cd}$ concentration $\left(200 \mathrm{mg} / \mathrm{dm}^{3}\right)$ and diminished by high levels of $\mathrm{Cd}$ concentration. It can be concluded that GPOX in $B$. vulgaris played a more key role in ROS scavenging than SOD did and was able to reduce the level of lipid peroxidation in plants. Our results indicate reliable correlations between cadmium content and the values of oxidative stress biomarkers in plant tissues. The estimated correlation coefficients confirmed that the studied parameters depend on cadmium concentration.

\section{References}

[1] Rombel-Bryzek A, Rajfur M, Zhuk O. The impact of copper ions on oxidative stress in garden cress Lepidium sativum. Ecol Chem Eng S. 2017;24:627-636. DOI: 10.1515/eces-2017-0041.

[2] Zinicovscaia I, Rudi L, Valuta A, Cepot L, Vergel K, Frontasyeva MV, et al. Biochemical changes in Nostoc linckia associated with selenium nanoparticles biosynthesis. Ecol Chem Eng S. 2016;23:559-569. DOI: 10.1515/eces-2016-0039. 
[3] Benavides MP, Gallego SM, Tomaro ML. Cadmium toxicity in plants. Braz J Plant Physiol. 2005;17:21-34. DOI: 10.1590/S1677-04202005000100003.

[4] ATSDR, Agency for Toxic Substance and Disease Registry, U.S. Toxicological Profile for Cadmium. Department of Health and Humans Services, Atlanta, Georgia, USA: Public Health Service, Centers for Disease Control;2005.

[5] Kumar R, Mishra RK, Mishra V, Qidwai A, Pandey A, Shukla SK, et al. Detoxification and tolerance of heavy metals in plants. In. Ahmad P, editor. Plant Metal Interaction. Chapter 13. USA: Elsevier Inc; 2016. DOI: 10.1016/B978-0-12-803158-2.00013-8.

[6] Galleo SM, Pena LB, Barcia RA, Azpilicueta CE, Iannone MF, Rosales MD. Unravelling cadmium toxicity and tolerance in plant: insight into regulatory mechanism. Environ Exp Bot. 2012;83:33-46. DOI: 10.1016/j.envexpbot.2012.04.006.

[7] Eutrópio FJ, Ramos AC, Da Silva Folli-Pereira W, De Aquino Portela N, Dos Santos JB, Da Conceição JM, et al. Heavy metal stress and molecular approaches in plants. In: Ahmad P, editor. Plant Metal Interact. 2016; Chapter 22. USA: Elsevier Inc; 2016. DOI: 10.1016/B978-0-12-803158-2.00022-9.

[8] Redjala T, Sterckeman T, Morel JL. Influence of plant cadmium content on root cadmium uptake. Proc Internat Plant Nutrition Colloquium XVI, 2009. https://escholarship.org/uc/item/5xw4q4pm.

[9] Song Y, Jin L, Wang X. Cadmium absorption and transportation pathways in plants. Int J Phytoremediat. 2017;19:133-141. DOI: 10.1080/15226514.2016.1207598.

[10] Ching KH. Cadmium stress in rice plants: influence of essential elements. Crop Env Bioinformat. 2014;11:113-118.

[11] Gill SS, Khan NA, Tuteja N. Cadmium at high dose perturbs growth, photosynthesis and nitrogen metabolism while at low dose it up regulates sulfur assimilation and antioxidant machinery in garden cress (Lepidium sativum L.). Plan Sci. 2012;182:112-120. DOI: 10.1016/j.plantsci.2011.04.018.

[12] Lehotai N, Peto A, Bajkal S, Erdei L, Tari I, Kolbert Z. In vivo and in situ visualization of early physiological events induced by heavy metals in pea root meristem. Acta Physiol. Plant. 2011;33:2199-2207. DOI 10.1007/s11738-011-0759-z.

[13] Moura DJ, Peres VF, Jacques RA, Saffi J. Heavy Metal Toxicity: Oxidative Stress Parameters and DNA Repair. In: Gupta DK, Sandalio LM, editors. Metal Toxicity in Plants: Perception, Signaling and Remediation. Berlin Heidelberg: Springer Verlag; 2012. DOI: 10.1007/978-3-642-22081-4.

[14] Gill SS, Tuteja N. Reactive oxygen species and antioxidant machinery in abiotic stress tolerance in crop plants. Plant Physiol Biochem. 2010;12:909-930. DOI: 10.1016/j.plaphy.2010.08.016.

[15] Gagne F. Oxidative stress. In: Biochemical Ecotoxicology. Principles and Methods. First edition, Chapter 6. London: Elsevier Inc; 2014. DOI: 10.1016/C2012-0-07586-2.

[16] Zaharieva T, Yamashita K, Matsumoto H. Iron deficiency induced changes in ascorbate content and enzyme activities related to ascorbate metabolism in cucumber roots. Plant Cell Physiol. 1999;40:273-280.

[17] Misra HP, Fridovich I. The role of superoxide anion in the autooxidation of epinephrine and simple assay for superoxide dismutase. J Biol Chem. 1972;247:3170-3175. http://www.jbc.org/content/247/10/3170.full.pdf.

[18] Bradford MM. Rapid and sensitive method for the quantitation of microgram quantities of protein utilizing the principle of protein-dye binding. Anal Biochem. 1976;72:248-254. DOI: 10.1016/0003-2697(76)90527-3.

[19] Lichtenthauer HK. Chlorophylls and carotenoids: pigments of photosynthetic biomembranes. Methods Enzymol. 1987;148:350-382. DOI: 10.1016/0076-6879(87)48036-1.

[20] Heath RL, Packer L. Photoperoxidation in isolated chloroplast. I. Kinetics and stoichiometry of fatty acid peroxidation. Arch Biochem Biophys. 1968;125:189-198. DOI: 10.1016/0003-9861(68)90654-1.

[21] Ibrahim MM, Bafeel SO. Alteration of gene expression, superoxide anion radical and lipid peroxidation induces by lead toxicity in leaves of Lepidium sativum. J Anim Plant Sci. 2009;4:281-288.

[22] Rajfur M, Krems P, Kłos A, Kozłowski R, Jóźwiak MA, Kř́̌ž J, et al. Application of algae in active biomonitoring of the selected holding reservoirs in Swietokrzyskie Province. Ecol Chem Eng S. 2016;23(2):237-247. DOI: 10.1515/eces-2016-0016.

[23] iCE 3000 Series AA Spectrometers Operators Manuals. Cambridge: Thermo Fisher Scientific; 2011. http://photos.labwrench.com/equipmentManuals/9291-6306.pdf.

[24] Loix C, Huybrechts M, Vangronsveld J, Gielen M, Keunen E, Cuypers A. Reciprocal interactions between cadmium-induced cell wall responses and oxidative stress in plants. Front Plant Sci. 2017;8:1-19. DOI: 10.3389/fpls.2017.01867.

[25] Mittler R. Oxidative stress, antioxidants and stress tolerance. Trends Plant Sci. 2002;7:405-410. DOI: 10.1016/S1360-1385(02)02312-9.

[26] Cuypers A, Keunen E, Bohler S, Jozefczak M, Opdenakker K, Gielen H, et al. Cadmium and copper stress induce a cellular oxidative challenge leading to damage versus signaling. In: Gupta DK, Sandalio LM, 
editors. Metal Toxicity in Plants: Perception, Signaling and Remediation. Berlin Heidelberg: Springer; 2012. DOI: $10.1007 / 978-3-642-22081-4 \_4$.

[27] Gajewska E, Skłodowska M, Słaba M, Mazur J. Effect of nickel on antioxidative enzyme activities proline and chlorophyll contents in wheat shoots. Biol Plantarum. 2006;50:653-659. DOI: 10.1007/s10535-006-0102-5.

[28] Lin A, Zhang X, Chen M, Cao Q. Oxidative stress and DNA damages induced by cadmium accumulation. J Environ Sci. 2007;19:596-602. http://www.jesc.ac.cn/jesc_en/ch/reader/create_pdf.aspx? file_no=2007190514.

[29] Shekhawat GS, Verma K, Jana S, Singh K, Teotia P, Prasad A. In vitro biochemical evaluation of cadmium tolerance mechanism in callus and seedlings of Brassica juncea. Protoplasma. 2010;239:31-38. DOI: 10.1007/s00709-009-0079-y.

[30] Ali B, Deng X, Hu X, Gill RA, Ali S, Wang S, et al. Deteriorative effects of cadmium stress on antioxidant system and cellular structure in germinating seeds of Brassica napus L. J Agr Sci Tech. 2015;17:63-74. http://citeseerx.ist.psu.edu/viewdoc/download?doi=10.1.1.872.1490\&rep=rep1\&type=pdf.

[31] Farooq MA, Ali S, Hameed A, Bharwana SA, Rizwan M, Ishaque W, et al. Cadmium stress in cotton seedlings: Physiological, photosynthesis and oxidative damages alleviated by glycinebetaine. S Afr J Bot. 2016;104:61-68. DOI: 10.1016/j.sajb.2015.11.006.

[32] Blokhina O, Virolainen E, Fagerstedt KV. Antioxidants, oxidative damage and oxygen deprivation stress: a review. Annal Botany. 2003;91:179-194. DOI: 10.1093/aob/mcf118.

[33] Smeets K, Cuypers A, Lambrechts A, Semane B, Hoet P, Van Laere A, et al. Induction of oxidative stress and antioxidative mechanisms in Phaseolus vulgaris after $\mathrm{Cd}$ application. Plant Physiol Biochem. 2005;43:437-44. DOI: 10.1016/j.plaphy.2005.03.007.

[34] Wang Z, Zhang YX, Huang ZB, Huang L. Antioxidative response of metal-accumulator and non-accumulator plants under cadmium stress. Plant Soil. 2008;310:137-149. DOI: 10.1007/s11104-008-9641-1.

[35] Martins LL, Mourato MP, Cardoso AI, Pinto AP, Mota AM, De Lurdes S, et al. Oxidative stress induced by cadmium in Nicotiana tabacum L.: effects on growth parameters, oxidative damage and antioxidant responses in different plant parts. Acta Physiol Plant. 2011;33:1375-1383. DOI: 10.1007/s11738-010-0671-y.

[36] Kapoor D, Kaur S, Bhardwaj R. Physiological and biochemical changes in Brassica juncea plants under Cd-induced stress. Biomed Res Int. 2014;726070. DOI: 10.1155/2014/726070.

[37] Markovska Y, Gorinova N, Nedkovska M, Miteva K. Cadmium-induced oxidative damage and antioxidant responses in Brassica juncea plants. Biol Plantarum. 2009;53:151-154.

[38] Lu Y, Li XR, He MZ, Wang ZN, Tan HJ. Nickel effects on growth and antioxidative enzymes activities in desert plant Zygophyllum xanthoxylon (Bunge) Maxim. Sci Cold Arid Reg. 2010;2:436-444. DOI: 10.3724/SP.J.1226.2010.00436.

[39] Harris NS, Taylor GJ. Cadmium uptake and partitioning in durum wheat during grain filling. BMC Plant Biol. 2013;13:103-119. DOI: 10.1186/1471-2229-13-103.

[40] Macfie SM, Mahrami S, McGarvey BD. Differential accumulation of cadmium in near-isogenic lines of durum wheat: no role for phytochelatins. Physiol Mol Biol Plants. 2016;22:461-472. DOI: 10.1007/s12298-016-0383-x.

[41] Peško M, Král'ová K, Masarovičová E. Response of Hypericum perforatum plants to supply of cadmium compounds containing different forms of selenium. Ecol Chem Eng S. 2010;17:279-287. http://tchie.uni.opole.pl/ece_s/S17_3/S3_2010.pdf

[42] Zhuk O, Rombel-Bryzek A. Oddziaływanie kadmu i kwasu salicylowego na aktywność metaboliczną Lepidium sativum L. (Effect of cadmium and salicylic acid on metabolic activity in Lepidium sativum L.) Proc ECOpole. 2016;10:379-388. DOI: 10.2429/proc.2016.10(1)04.

[43] Seth CS, Kumar Chaturvedi P, Misra V. The role of phytochelatins and antioxidants in tolerance to Cd accumulation in Brassica juncea L. Ecotoxicol Environ Saf. 2008;71:76-85. DOI: 10.1016/j.ecoenv.2007.10.030. 